\title{
The physiological basis for genetic variation in water use efficiency and carbon isotope composition in Arabidopsis thaliana
}

\author{
Hsien Ming Easlon • Krishna S. Nemali • \\ James H. Richards • David T. Hanson • \\ Thomas E. Juenger $\cdot$ John K. McKay
}

Received: 20 October 2012/ Accepted: 10 July 2013/Published online: 28 July 2013

(C) The Author(s) 2013. This article is published with open access at Springerlink.com

\begin{abstract}
Ecologists and physiologists have documented extensive variation in water use efficiency (WUE) in Arabidopsis thaliana, as well as association of WUE with climatic variation. Here, we demonstrate correlations of whole-plant transpiration efficiency and carbon isotope composition $\left(\delta^{13} \mathrm{C}\right)$ among life history classes of $A$. thaliana. We also use a whole-plant cuvette to examine patterns of co-variation in component traits of WUE and $\delta^{13} \mathrm{C}$. We find that stomatal conductance $\left(g_{\mathrm{s}}\right)$ explains more variation in WUE than does $A$. Overall, there was a strong genetic correlation between $A$ and $g_{\mathrm{s}}$, consistent with selection acting on the ratio of these traits. At a more detailed level, genetic variation in $A$ was due to underlying variation in both maximal rate of carboxylation $\left(V_{\mathrm{c}} \max \right)$ and maximum electron transport rate $(J \max )$. We also found strong effects of leaf anatomy, where lines with lower WUE had higher leaf water content (LWC) and specific leaf area (SLA),
\end{abstract}

H. M. Easlon · K. S. Nemali · J. H. Richards

Department of Land, Air \& Water Resources, University

of California, Davis, CA 95616, USA

e-mail: heaslon@ucdavis.edu

K. S. Nemali

e-mail: krishna.nemali@monsanto.com

J. H. Richards

e-mail: jhrichards@ucdavis.edu

Present Address:

H. M. Easlon

Department of Plant Sciences, University of California, Davis,

CA 95616, USA

Present Address:

K. S. Nemali

Monsanto Company, Jerseyville, IL 62052, USA suggesting a role for mesophyll conductance $\left(g_{\mathrm{m}}\right)$ in variation of WUE. We hypothesize that this is due to an effect through $g_{\mathrm{m}}$, and test this hypothesis using the abi4 mutant. We show that mutants of ABI4 have higher SLA, LWC, and $g_{\mathrm{m}}$ than wild-type, consistent with variation in leaf anatomy causing variation in $g_{\mathrm{m}}$ and $\delta^{13} \mathrm{C}$. These functional data also add further support to the central, integrative role of $\mathrm{ABI} 4$ in simultaneously altering $\mathrm{ABA}$ sensitivity, sugar signaling, and $\mathrm{CO}_{2}$ assimilation. Together our results highlight the need for a more holistic approach in functional studies, both for more accurate annotation of gene function and to understand co-limitations to plant growth and productivity.

Keywords ABI4 - Carbon isotope composition . Mesophyll conductance · Photosynthetic capacity · Stomatal conductance

\section{T. Hanson}

Department of Biology, University of New Mexico,

Albuquerque, NM 87131, USA

e-mail: dthanson@unm.edu

T. E. Juenger

Section of Integrative Biology, University of Texas, Austin, TX 78712, USA

e-mail: tjuenger@austin.utexas.edu

J. K. McKay ( $\square)$

Department of Bioagricultural Sciences \& Pest Management, Colorado State University, Fort Collins, CO 80523, USA

e-mail: jkmckay@colostate.edu 


\section{Introduction}

The efficiency with which plants fix $\mathrm{CO}_{2}$ relative to their rate of $\mathrm{H}_{2} \mathrm{O}$ loss is called water use efficiency (WUE), and when high, WUE can mitigate the tradeoff between $\mathrm{CO}_{2}$ uptake and $\mathrm{H}_{2} \mathrm{O}$ loss. In $\mathrm{C}_{3}$ plants, low stomatal conductance $\left(g_{\mathrm{s}}\right)$ minimizes water loss (transpiration, $\left.E\right)$ and can be a rapid and effective strategy; however, it results in reduced $\mathrm{CO}_{2}$ uptake $(A)$ and growth (Schulze 1986; Geber and Dawson 1997; Condon et al. 2002). Genetically based variation in WUE has been documented in both crops and non-cultivated species (McKay et al. 2003; Hall et al. 2005). Physiologists are interested in intrinsic WUE $\left(A / g_{s}\right)$ as a tool for studying how the fundamental trade-off of losing water for gaining $\mathrm{CO}_{2}$ is regulated by stomatal and other physiological adjustments (Buckley and Mott 2002; Comstock 2002). Evolutionary biologists have studied variation in WUE as it is likely an important component of local adaptation (Donovan and Ehleringer 1994; Heschel et al. 2002; Geber and Griffen 2003; Caruso et al. 2005). Likewise, plant breeders have long considered WUE an important target (Passioura 1977).

WUE can be estimated in a variety of ways at various spatio-temporal scales, including with lysimeter studies, gas exchange measurements, or stable carbon isotope composition. Tissue carbon isotope composition is an increasingly popular approach, and its advantages include integration over long periods of gas exchange and development, amenability to high throughput sampling, relatively low cost, and high heritability. Stable carbon isotope composition of leaves $\left(\delta^{13} \mathrm{C}\right)$ (the ratio of the amount of ${ }^{13} \mathrm{C}$ to ${ }^{12} \mathrm{C}$ isotopes in a sample relative to a standard), provides a time-integrated estimate of intrinsic WUE (Farquhar et al. 1989; Dawson et al. 2002). In Arabidopsis thaliana (here after Arabidopsis), common garden experiments have identified substantial variation in $\delta^{13} \mathrm{C}$ among natural accessions and some of this variation likely represents local adaptation to climate (McKay et al. 2003, 2008; Juenger et al. 2005, 2010; Christman et al. 2008; Monda et al. 2011; Des Marais et al. 2012; Lasky et al. 2012). In addition, QTL have been identified for $\delta^{13} \mathrm{C}$ (Juenger et al. 2005; Masle et al. 2005; McKay et al. 2008).

In plant breeding, WUE is an important target of selection, although the complexity of the trait, and difficulty of phenotyping has prevented many breeding programs from attempting to select on WUE directly (Araus et al. 2002). Many studies have shown variation in $\delta^{13} \mathrm{C}$ among cultivars. In crops, one particularly successful example is an Australian wheat breeding program, where selection on $\delta^{13} \mathrm{C}$ in a greenhouse environment led to new varieties that had increased yield in semiarid rainfed conditions (Rebetzke et al. 2002). Conversely, in conditions where water is not limiting, selection for reduced WUE may lead to greater yields (Passioura 1977; Fischer et al. 1998).

Although it is heritable, appears to be under selection in nature, and may correlate with yield in $\mathrm{C}_{3}$ crops (Condon et al. 1987), the mechanistic basis of genetic variation in $\delta^{13} \mathrm{C}$ is still unclear. Variation in $\delta^{13} \mathrm{C}$ can be due to variation in photosynthetic biochemistry, conductance of $\mathrm{CO}_{2}$ to the leaf interior and chloroplast, or a combination of these (Seibt et al. 2008). Thus, similar leaf $\delta^{13} \mathrm{C}$ and similar WUE can evolve via mutations that cause low $A$ with low conductance or mutations that cause high $A$ with proportionally higher conductance (Farquhar et al. 1989). This is further complicated because conductance from ambient air to the interior of the leaf is influenced both by $g_{\mathrm{s}}$ and additional variability of conductance into leaf mesophyll cells and chloroplasts $\left(g_{\mathrm{m}}\right)$, which can change over the long-term with leaf morphology (von Caemmerer and Evans 1991; Evans et al. 1994, 2009; Tosens et al. 2012) and over the short-term through changes in protein-mediated chloroplast membrane permeability (Flexas et al. 2006; Uehlein et al. 2008; Heckwolf et al. 2011). When examining the combined effects of $g_{\mathrm{s}}$ and $g_{\mathrm{m}}$, it is important to recognize that they operate in series rather than in parallel and that the regulation of $g_{\mathrm{m}}$ is poorly understood. Within a genotype, $g_{\mathrm{s}}$ and $g_{\mathrm{m}}$ usually respond in a correlated way to environmental stimuli (Flexas et al. 2007, 2008; Warren 2008; Barbour et al. 2010) although, opposite responses have also been observed (Galle et al. 2012). Patterns of genetic covariation of $g_{\mathrm{s}}$ and $g_{\mathrm{m}}$ have not been investigated. However, it is known that variation in $g_{\mathrm{m}}$ contributes to leaf carbon isotope discrimination, further increasing the importance of considering $g_{\mathrm{s}}$ and $g_{\mathrm{m}}$ in interpretations of $\delta^{13} \mathrm{C}$ (Warren and Adams 2006; Barbour et al. 2010).

Understanding the physiological basis of variation in $\delta^{13} \mathrm{C}$ and intrinsic WUE is important for improving plant productivity and understanding the evolution of wild species. Here, we report a series of experiments designed to investigate a mechanistic understanding of the physiological basis of variation in intrinsic WUE in Arabidopsis. At the coarse level, we can ask if variation in intrinsic WUE is primarily due to variation in $A$ or $g_{\mathrm{s}}$. For example, threefold variation in $g_{\mathrm{s}}$ and twofold variation in leaf $N$ concentration among natural accessions of Arabidopsis suggest substantial variation in $g_{\mathrm{s}}$ and $A$ may separately or in concert be responsible for the observed variation in $\delta^{13} \mathrm{C}$ (Christman et al. 2008; Des Marais et al. 2012). Des Marais et al. (2012) found large differences in physiology between life history classes in Arabidopsis. Although, the Des Marais study focused on variation in gene expression, they also reported constitutive variation in leaf structural traits between life history classes. Winter annual types had higher intrinsic WUE. This is consistent with coordinated selection on 
WUE, $A$, and $g_{\mathrm{s}}$ and life history observed in other species (Geber and Dawson 1997). Higher WUE was associated with lower leaf water content (LWC) and specific leaf area (SLA) (Des Marais et al. 2012). Taken together, these results suggest that increased leaf density is associated with higher photosynthetic capacity (Terashima et al. 2011), but may come at the cost of lower stomatal and mesophyll conductance to $\mathrm{CO}_{2}$ (Parkhurst and Mott 1990; Evans et al. 1994; Syvertsen et al. 1995; Kogami et al. 2001).

Studies in Arabidopsis have identified extensive natural variation in plant-water relations and gas exchange physiology (Juenger et al. 2005, 2010; Masle et al. 2005; Bouchabke et al. 2008; Christman et al. 2008; McKay et al. 2008; Monda et al. 2011; Des Marais et al. 2012; Pons 2012). The present study was undertaken to examine natural variation in leaf physiological traits that are the likely cause of the observed variation in $\delta^{13} \mathrm{C}$ and associated WUE parameters in natural accessions of Arabidopsis, and to determine if these traits vary independently or co-vary in a coordinated and predictable manner. First, we tested if the expected relationship between transpiration efficiency (shoot dry mass/transpiration; TE) and leaf $\delta^{13} \mathrm{C}$ was present in 96 natural accessions of Arabidopsis. In a smaller set of 18 natural accessions spanning the range of variation in $\delta^{13} \mathrm{C}$, we measured rosette $A, g_{\mathrm{s}}$, and intercellular $\mathrm{CO}_{2}$ concentration $\left(C_{\mathrm{i}}\right)$ and examined the relationship of $C_{\mathrm{i}}$ and $\delta^{13} \mathrm{C}$. To further characterize natural variation in $A$, we examined maximal carboxylation rate $\left(V_{\mathrm{c}} \max \right)$ and photosynthetic electron transport rate $(J \max )$ in three accessions using photosynthetic carbon dioxide response curves (Sharkey et al. 2007). Additionally, we used gas exchange measurements coupled with online isotopic measurements to determine instantaneous carbon isotope discrimination using tunable diode laser spectroscopy (TDL) (Flexas et al. 2006; Barbour et al. 2007; Heckwolf et al. 2011) to estimate $g_{\mathrm{m}}$ in stomatal regulation mutants to investigate the relationship of these mechanistically related traits (Warren et al. 2003; Yamori et al. 2006).

\section{Materials and methods}

\section{$\delta^{13} \mathrm{C}$ and transpiration efficiency (Experiment 1)}

Our first goal was to use a relatively high throughput approach to look for variation and co-variation across the species range. 96 natural accessions were selected from the native range of Arabidopsis to evaluate plant biomass production and water use (Nordborg et al. 2005). Individual plants were grown in $250-\mathrm{mL}$ plastic cups, each filled with a standard mass of 1:1 fritted clay and Promix BT potting soil mix. We measured field capacity of the soil mix following a 24-h gravitational drain of saturated soil. Each cup was covered with parafilm and sealed with a plastic lid that had a 6-mm diameter hole. Two replicates of each of 96 ecotypes were planted and cold stratified in the dark for 7 days at $4{ }^{\circ} \mathrm{C}$. Plants were grown in two independent growth chambers at $200 \mu \mathrm{mol} \mathrm{m} \mathrm{s}^{-2} \mathrm{~s}^{-1}$ PPFD in a randomized block design. Photoperiod was $12 \mathrm{~h}$ light/12 h dark and the temperature cycled $23 / 18{ }^{\circ} \mathrm{C}$ (light/dark). Every 2 days, each container was weighed and additional water was added with a syringe to bring the soil in each container to $90 \%$ field capacity. Total transpiration $\left(E_{\text {total }}\right)$ was summed for the 35 days growing period for each experimental plant. Plants were harvested, and aboveground material was oven dried and weighed (DW). We assessed evaporative loss from the containers using "blanks" lacking an Arabidopsis plant. Total evaporation from the blank containers was $<4 \%$ of the average $E_{\text {total }}$ from pots in the experiment. Transpiration efficiency (TE) of each plant was calculated as DW/ $E_{\text {total }}$. Dried leaves were ground to a fine powder and $\delta^{13} \mathrm{C}$ was determined at the UC Davis Stable Isotope Facility (http://stableisotope facility.ucdavis.edu/). When grown outside in free air, the use of carbon isotope discrimination, $\Delta$, is preferred (Farquhar et al. 1982), but when growth chamber and greenhouse studies are included the value of air $\delta^{13} \mathrm{C}$ is uncertain and variable, thus requiring the use of leaf $\delta^{13} \mathrm{C}$ instead of $\Delta$. Differences in $\delta^{13} \mathrm{C}$ within the same experiment indicate differences in intercellular $\mathrm{CO}_{2}$ concentration, but $\delta^{13} \mathrm{C}$ must be viewed with caution when comparing different experimental conditions.

\section{Whole-shoot gas exchange (Experiment 2)}

To follow up on the patterns from the 96 accessions, 18 natural accessions of Arabidopsis were used in whole-shoot gas exchange experiments to evaluate the physiological basis of variation in $\delta^{13} \mathrm{C}$. Eleven of the accessions were spring annuals, and seven were winter annuals. Four replicates of each genotype were grown in a growth chamber in a randomized block design. Each plant was grown in a pot constructed from a 50-mL centrifuge tube with the bottom cut off and "planted" in a 164-mL Conetainer ${ }^{\mathrm{TM}}$ pots (Stuewe and Sons, Corvallis, OR) filled with a 1:1 mixture of potting mix (Sunshine mix, Sun Gro Horticulture, Bellevue, WA) and fritted clay. After planting, pots were cold stratified at $4{ }^{\circ} \mathrm{C}$ for 7 days, then transferred to a growth chamber. Photoperiod was $12 \mathrm{~h}$ with $350 \mu \mathrm{mol} \mathrm{m} \mathrm{m}^{-2} \mathrm{~s}^{-1}$ PPFD and temperature was cycled $23 / 20{ }^{\circ} \mathrm{C}$ (light/dark).

Instantaneous whole-canopy gas exchange rate was measured using a LI-6400 (Li-Cor Inc., Lincoln, NE, USA) with a custom-made whole-shoot Arabidopsis cuvette (Fig. 1). Cuvette PPFD was maintained at $350 \mu \mathrm{mol} \mathrm{m}^{-2} \mathrm{~s}^{-1}$ PPFD, $\mathrm{CO}_{2}$ was maintained at $400 \mu \mathrm{mol} \mathrm{mol}{ }^{-1}$, and temperature 

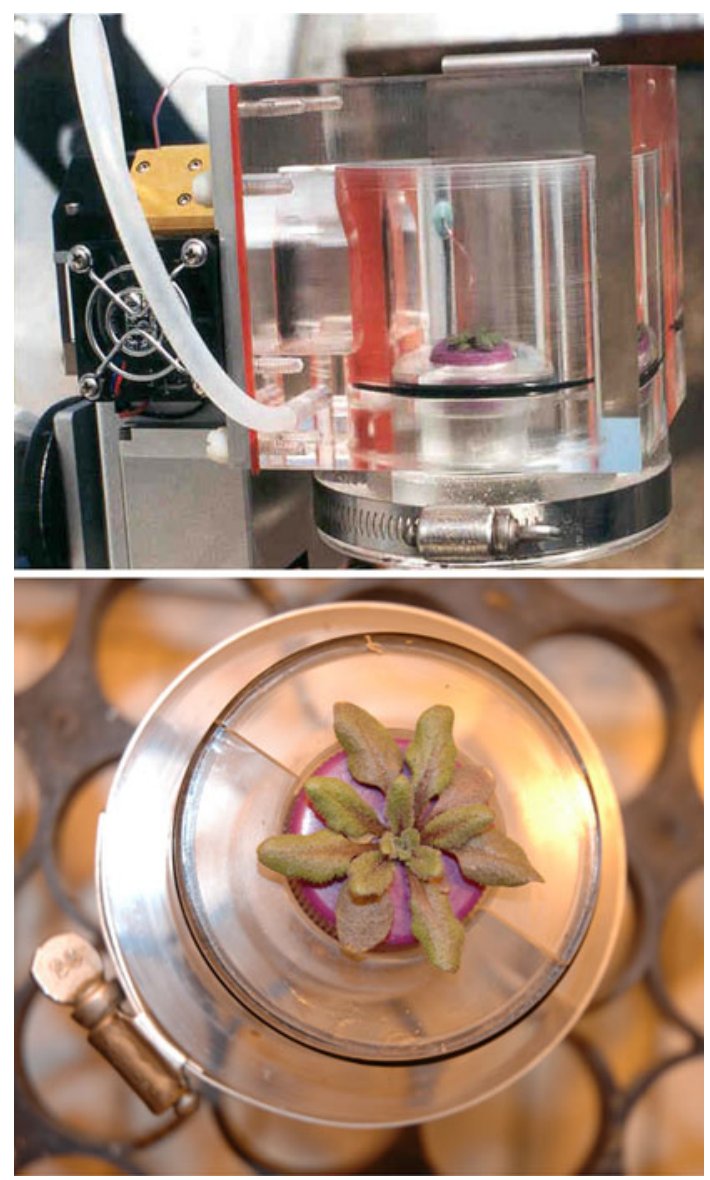

Fig. 1 Cuvette used for whole-plant gas exchange measurements. The cuvette is mounted on the LI-6400 IRGA and cuvette control system (gold-plated panel, fan and aluminum box, upper photograph). This system allows accurate, rapid measurement of $\mathrm{CO}_{2}(A)$ and $\mathrm{H}_{2} \mathrm{O}$ (E) exchange of whole shoots of Arabidopsis plants. The whole-plant cuvette incorporates a leaf temperature thermocouple that interfaces directly with the LI-6400. Intrinsic WUE $\left(A / g_{\mathrm{s}}\right)$, stomatal conductance $\left(g_{\mathrm{s}}\right)$, internal $\mathrm{CO}_{2}$ concentration $\left(C_{\mathrm{i}}\right)$, and other variables can be calculated from these measurements. All interior surfaces are Teflon coated or Ni-plated, the cuvette has extremely low leak rates when operated in lab conditions with high external $\mathrm{CO}_{2}$, and the circular design provides excellent mixing using the LI-6400 fans. Plants can be rapidly changed using multiple inserts (lower photo)

and relative humidity were set to growth chamber conditions. Each block was measured on a different day, 28-31 days after sowing. Following measurements for each plant, leaf area was determined from digital photographs of the rosette using Scion Image (Scion Corporation, Frederick, MD, USA).

$A: C_{\mathrm{i}}$ responses were measured for three accessions (Tsu1, SQ-8, and Kas-1) which differed in $A$ and $\delta^{13}$ C. Cuvette conditions were the same as above, but light was increased to $1,000 \mu \mathrm{mol} \mathrm{m}{ }^{-2} \mathrm{~s}^{-1}$ PPFD. Photosynthetic carbon dioxide response curves were measured on four rosettes of each accession. The number of replications of $A: C_{\mathrm{i}}$ measurements were limited by chamber environment equilibration time at each $\mathrm{CO}_{2}$ set point. The least squares iterative curve-fitting procedure (Sharkey et al. 2007) model was used to fit Farquhar et al.'s (1980) biochemical model of photosynthesis and obtain maximal carboxylation rate $\left(V_{\mathrm{c}} \max \right)$ and maximal photosynthetic electron transport rate (Jmax).

\section{Leaf water content (Experiment 3)}

39 natural accessions from the native range of Arabidopsis previously used in Mckay et al. (2003) were measured for LWC and leaf $\delta^{13} \mathrm{C}$. Four replicates of each ecotype were grown in a greenhouse at UC Davis in a randomized block design. Seeds were sown in $250-\mathrm{mL}$ pots in peat-based potting mix with slow-release fertilizer and vernalized at $4{ }^{\circ} \mathrm{C}$ for 5 days. Day length was extended to $16 \mathrm{~h}$ using supplemental lighting at $350 \mu \mathrm{mol} \mathrm{m} \mathrm{s}^{-2} \mathrm{~s}^{-1}$ PPFD. Greenhouse mean relative humidity and air temperature were $44 \%$ and $23{ }^{\circ} \mathrm{C}$, respectively. Shoots were harvested at the initiation of flowering and shoot fresh weight (FW) was determined, leaf area was determined from scans of dissected rosettes using Scion Image (Scion Corporation, Frederick, MD, USA), and shoots were dried and weighed (DW). Entire dried shoots were ground and processed for carbon isotope analysis at the UC Davis Stable Isotope Facility (http://stableisotopefacility.ucdavis.edu/). LWC (\%) was calculated as $100 \times(\mathrm{FW}-\mathrm{DW}) / \mathrm{DW}$.

\section{Mesophyll conductance (Experiment 4)}

Arabidopsis seeds of ecotype Columbia and the abi4 mutant provided by the Arabidopsis Biological Resource Center (Columbus, OH, USA) were used for leaf mesophyll conductance to $\mathrm{CO}_{2}\left(g_{\mathrm{m}}\right)$ experiments. Seven replicates of each genotype were grown in a growth chamber in a randomized block design. Photoperiod was $12 \mathrm{~h}$ with $350 \mu \mathrm{mol} \mathrm{m} \mathrm{m}^{-2} \mathrm{~s}^{-1}$ PPFD and temperature was cycled $23 / 20^{\circ} \mathrm{C}$ (light/dark). A LI-6400 (Li-Cor Inc., Lincoln, NE, USA) with wholeshoot Arabidopsis cuvette (Fig. 1) was coupled with online isotopic measurements of $\mathrm{CO}_{2}$ entering and leaving the shoot chamber to determine instantaneous carbon isotope discrimination and $g_{\mathrm{m}}$ using TDL (Flexas et al. 2006; Barbour et al. 2007; Heckwolf et al. 2011). Calculations for $g_{\mathrm{m}}$ were based on whole-shoot gas exchange measurements at 350 , 700, and $175\left(\mu \mathrm{mol} \mathrm{m}{ }^{-2} \mathrm{~s}^{-1}\right)$ PPFD using the slope-based approach given in Evans et al. (1986). Shoots were harvested after gas exchange, leaf area was determined from rosette photographs using Scion Image (Scion Corporation, Frederick, MD, USA), and shoots were dried and weighed (DW). LWC (\%) was calculated as above and SLA was calculated as rosette area/DW.

\section{Statistical analysis}

We analyzed phenotypic data for physiological traits using standard fixed effect ANOVAs with the Proc GLM in SAS 
(SAS Institute 1999). We estimated correlations among physiological traits as the standard Pearson product-moment correlation between genotype means.

In the case of the TE experiment, we analyzed phenotypic data for physiological traits using a linear mixed model analysis with the Proc Mixed procedure in SAS (SAS Institute 1999). We fit a model including accessions as a random effect and chamber, experiment, and their interaction as fixed effects. The variance component for the random effect was estimated using restricted maximum likelihood (REML) and assessments of significance were based on likelihood ratio tests (Little et al. 1996). We obtained empirical best linear unbiased predictors (BLUPs) associated with the random effects and consider these breeding values for each accessions. BLUPs are robust estimates of the impact of a particular accession on the measured trait while controlling for the fixed effects (chamber and experimental run). For TE, we fit a model that included both chamber and experimental run as a fixed effect. For $\delta^{13} \mathrm{C}$, we fit a simpler model including accession as a random variable and experimental run as a fixed effect. In this case, factors associated with chamber could not be included because replicates within each experimental run were pooled for mass spectroscopy analysis. All subsequent analyses involving TE and $\delta^{13} \mathrm{C}$ rely on BLUP estimates. The TE and $\delta^{13} \mathrm{C}$ values were normally distributed and residuals from analyses did not exhibit heteroscedasticity.

We estimated broad-sense heritability by computing the ratio $V_{\mathrm{G}} / V_{\mathrm{P}}$, where $V_{\mathrm{G}}$ equals the among-accession variance component and $V_{\mathrm{P}}$ equals the total phenotypic variance for the study phenotypes. We estimated genetic correlations $\left(r_{\mathrm{G}}\right)$ among $\mathrm{TE}$ and $\delta^{13} \mathrm{C}$ as the standard Pearson product-moment correlation between genotype means or BLUPs.

\section{Results and discussion}

\section{Variation in TE and $\delta^{13} \mathrm{C}$}

The 96 natural accessions of Arabidopsis in experiment 1 (Table 1) exhibited considerable variation in time-integrated measures of water use efficiency, i.e., whole-plant TE and $\delta^{13} \mathrm{C}$. We observed a $3.33 \mathrm{~g} \mathrm{~kg}^{-1}$ and $5.12 \%$ range of variation in $\mathrm{TE}$ and $\delta^{13} \mathrm{C}$ among accessions, respectively, $\left(\right.$ TE mean $\left.=2.02 \pm 0.28 \mathrm{~g} \mathrm{~kg}^{-1}\right)\left(\delta^{13} \mathrm{C}\right.$ mean $=-30.64 \pm$ $0.90 \%$ ). In both cases, we observed significant broad-sense heritability (TE, $H^{2}=0.09$, accession $P=0.031 ; \delta^{13} \mathrm{C}$, $H^{2}=0.667$, accession $P=0.001$ ). For the experiment 1 , we found replication block, growth chamber, and their interaction were significant sources of environmental variation in TE (in all cases, $P<0.005$ ). Likewise, we found that the replication block was a significant source of environmental variation for $\delta^{13} \mathrm{C}(P<0.0001)$. Despite the low heritability of the TE data, our experimental design and analysis allowed us to estimate breeding values as BLUPs. Spring accessions fit the expected positive relationship between TE and $\delta^{13} \mathrm{C}$ $\left(r_{\mathrm{G}}^{2}=0.265, P<0.0001\right.$, Fig. 2). The winter annuals had greater intrinsic WUE as indicated by $\delta^{13} \mathrm{C}$ than the spring annuals, but this was not related to $\mathrm{TE}\left(r_{\mathrm{G}}^{2}=0.011\right.$, $P=0.531$, Fig. 2). Together these data suggest that variation in $\delta^{13} \mathrm{C}$ is likely due to stomatal limitations (on $C_{\mathrm{i}}$ ) in the spring accessions, but in winter accessions, other mechanisms (like $g_{\mathrm{m}}$ ) not affecting water loss may be leading to variation in $\delta^{13} \mathrm{C}$ (Seibt et al. 2008). Alternatively, variation in root carbon allocation unaccounted for in TE may explain the observed pattern in winter accessions. In principle, the greater belowground allocation in winter accessions could result in lower TE without affecting $\delta^{13} \mathrm{C}$, but this hypothesis remains to be tested.

\section{Variation in components of WUE}

The 18 natural accessions of Arabidopsis in experiment 2 were selected to represent a wide range of intrinsic WUE as indicated by $\delta^{13} \mathrm{C}$ (Table 1). Whole-plant gas exchange measurements in a custom cuvette (Fig. 1) showed that these lines also exhibit considerable variation in whole rosette $A$ and $g_{\mathrm{s}}$ in a common environment (Fig. 3). Accession mean whole rosette $A$ ranged between 10 and $16 \mu \mathrm{mol} \mathrm{m}{ }^{-2} \mathrm{~s}^{-1}$, but the heritability was not significantly different from zero $(P=0.137) . g_{\mathrm{s}}$ showed significant genetic variation, ranging between 0.17 and $0.45 \mathrm{~mol} \mathrm{~m}^{-2} \mathrm{~s}^{-1}$ with a heritability of $H^{2}=0.33$ (accession $P$ value $=0.002$ ). In addition, $g_{\text {s }}$ was a better predictor of variation in $\delta^{13} \mathrm{C}$ than $A$. We found a significant negative correlation between $\delta^{13} \mathrm{C}$ and $g_{\mathrm{s}}$ among accessions $\left(r^{2}=0.40, P=0.0027\right)$, and a weaker correlation between $\delta^{13} \mathrm{C}$ and $A\left(r^{2}=0.25, P=0.036\right)$. In general, the high conductance lines had low intrinsic WUE, as indicated by $\delta^{13} \mathrm{C}$, but there was a wide range of $\delta^{13} \mathrm{C}$ in the low conductance lines, suggesting additional sources of variation. The expected negative correlation between $\delta^{13} \mathrm{C}$ and $g_{\mathrm{s}}$ was largely caused by the spring accessions. The winter accessions tended to show the opposite pattern (not significant), with the exception of Tamm-2, an accession from Finland that had the highest $g_{\mathrm{s}}$ of all.

Despite the lack of heritability of $A$ and the weak correlation of $A$ with $\delta^{13} \mathrm{C}$, we did find a significant positive correlation between $g_{\mathrm{s}}$ and $A$ among accessions $\left(r^{2}=0.78\right.$, $P=0.00001)$. This is consistent with the optimization of stomatal regulation to maximize carbon gain while minimizing the water loss (Katul et al. 2010). Accessions that have high conductance should be under selection for increased biochemical capacity (Bloom et al. 1985). 
Table 1 Summary of experiments

\begin{tabular}{|c|c|c|c|}
\hline Experiment & Genotypes & Measurements & Conditions \\
\hline Experiment 1 & $\begin{array}{l}96 \text { natural accessions representing a range of } \\
\text { latitudes, elevations and climates. }\end{array}$ & $\mathrm{TE}, \delta^{13} \mathrm{C}$ & $\begin{array}{l}200 \mu \mathrm{mol} \mathrm{m}^{-2} \mathrm{~s}^{-1} \text { PPFD, } \\
12 \mathrm{~h} \text { photoperiod }\end{array}$ \\
\hline Experiment 2 & $\begin{array}{l}\text { Ag-0, Bil-5, Bur-0, C24 } \\
\text { Col-2, Eden-1, } \\
\text { Got-22, HR5, Kas-1, } \\
\text { Knox-18, Ler-1, NFA-10, } \\
\text { Omo2-3, Sq-8, Tamm-2, } \\
\text { Ts-1, Tsu-1, Ws-2 }\end{array}$ & $\begin{array}{l}\text { Whole shoot gas exchange } \\
\qquad\left(A, g_{\mathrm{s}}, C_{\mathrm{i}}\right), \delta^{13} \mathrm{C}, V_{\mathrm{c}} \max , J \max \end{array}$ & $\begin{array}{l}350 \mu \mathrm{mol} \mathrm{m}^{-2} \mathrm{~s}^{-1} \text { PPFD, } \\
12 \mathrm{~h} \text { photoperiod }\end{array}$ \\
\hline Experiment 3 & $\begin{array}{l}\text { Aa-0, Ag-0, Cvi-0, Kas-1, Mh-0, Ms-0, Di-g, } \\
\text { Est, Ws-3, Kondara, Da(1)-12, Hodja-Obi- } \\
\text { garm, Je54, Petergof, Rubezhnoe-1, Sn(5)- } \\
\text { 1, Sorbo, An-1, Bch-3, Can-0, Db-1, Edi-0, } \\
\text { Ei-4, En-1, Et-0, Jl-3, Ka-0, Mrk-0, Pi-0, } \\
\text { Rd-0, Rsch-4, Sei-0, Ta-0, W1-0, Wei-1, } \\
\text { Tsu-1, Rld-2, Oy-1, Shahdara }\end{array}$ & LWC, $\delta^{13} \mathrm{C}$ & $\begin{array}{l}350 \mu \mathrm{mol} \mathrm{m}{ }^{-2} \mathrm{~s}^{-1} \mathrm{PPFD}, \\
16 \mathrm{~h} \text { photoperiod }\end{array}$ \\
\hline Experiment 4 & abi4-1 (At2g40220), Columbia & $\begin{array}{l}\text { Whole shoot gas exchange with } \\
\text { online carbon isotope } \\
\text { discrimination }\left(A, g_{\mathrm{s}}, C_{\mathrm{i}}, g_{\mathrm{m}}\right. \\
\text { SLA, LWC) }\end{array}$ & $\begin{array}{l}350 \mu \mathrm{mol} \mathrm{m}^{-2} \mathrm{~s}^{-1} \text { PPFD, } \\
12 \mathrm{~h} \text { photoperiod }\end{array}$ \\
\hline
\end{tabular}

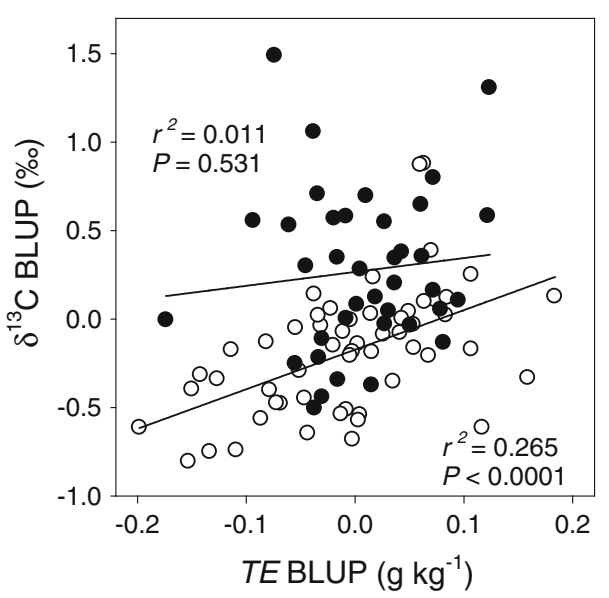

Fig. 2 Relationships of transpiration efficiency (TE) and leaf carbon isotope composition $\left(\delta^{13} \mathrm{C}\right)$ among 96 natural accessions of Arabidopsis thaliana. Symbols represent best linear unbiased predictors (BLUPs) associated with breeding values for each accession (see text). Open and filled symbols represent spring and winter accession means, respectively. Lines represent linear regression; $r^{2}$ and $P$ values are given

Although, it is not formally stated, such optimality approaches interpret consistent patterns of correlation in physiological traits (Reich et al. 1997) as evidence of selection optimizing their ratios or covariances (Donovan et al. 2011). Under such a scenario, selection would favor mutations that lead to a co-limitation of $g_{s}$ and RuBP utilization and regeneration.

In general, winter Arabidopsis accessions had lower $g_{\mathrm{s}}$ and $A$ than spring Arabidopsis accessions. Across accessions there was large variation in $C_{\mathrm{i}} / C_{\mathrm{a}}$, but it was only weakly related to $\delta^{13} \mathrm{C}$ (Fig. 4). No consistent difference in $C_{\mathrm{i}} / C_{\mathrm{a}}$ was seen between the winter and spring annuals.

The overall finding of experiment 2 was that accessions with low $g_{\mathrm{s}}$ and high $\delta^{13} \mathrm{C}$ had lower $A$ compared to low $\delta^{13} \mathrm{C}$ accessions. Overall, these data are consistent with large effects of $g_{\mathrm{s}}$ on $\delta^{13} \mathrm{C}$, but the weaker correlation of $C_{\mathrm{i}}$ and $\delta^{13} \mathrm{C}$ suggest a more complex mechanism than predicted by theory. To better understand processes limiting photosynthesis in Arabidopsis accessions, we conducted detailed $\mathrm{CO}_{2}$ response curves of assimilation for low and high WUE spring accessions Tsu-1 and SQ-8 and high WUE winter accession Kas-1. Maximum carboxylation rate of rubisco $\left(V_{\mathrm{c}} \max \right)$ was higher in low WUE Tsu-1 $\left(\delta^{13} \mathrm{C}=-29.7\right)$ than $\mathrm{Sq}-8\left(\delta^{13} \mathrm{C}=-28.6\right)$ $(P=0.01)$, as expected (Fig. 5). Similar, maximal photosynthetic electron transport $(J \max )$ was also higher in Tsu-1 than Sq-8 or Kas-1 $\left(\delta^{13} \mathrm{C}=-28.8\right)(P=0.002$, $P=0.002$ ).

The major biochemical limitations to photosynthesis, $V_{\mathrm{c}} \max$ and $J$ max, appeared optimized to accessions' $C_{\mathrm{i}}$ as indicated by $\delta^{13} \mathrm{C}$. $V_{\mathrm{c}} \max$ and $J \max$ were lower in low $g_{\mathrm{s}}$, high WUE accessions operating at lower $C_{\mathrm{i}}$. The higher ratio of $V_{\mathrm{c}}$ max to $J$ max in Kas-1 compared to $\mathrm{Sq}-8$ suggests a lack of limitation by Jmax under the low $g_{\mathrm{s}}$ typical of Kas-1. Simultaneous changes in $V_{\mathrm{c}} \max$ and $J \max$ are consistent with a limitation of photosynthesis by RuBP utilization and regeneration (Farquhar and Sharkey 1982). Likewise, proportional changes in components of photosynthetic apparatus and $g_{\mathrm{s}}$ suggest acclimation of these processes are closely coupled (Cowan 1986). 

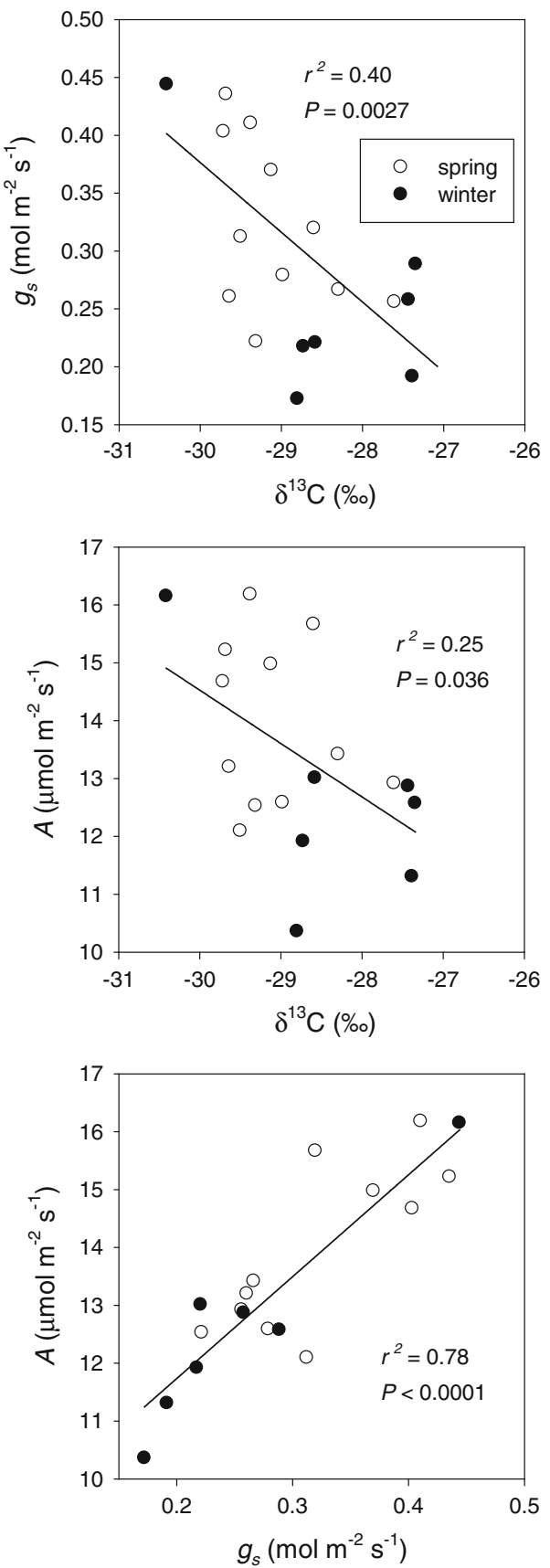

Fig. 3 Relationships between assimilation $(A)$, stomatal conductance $\left(g_{s}\right)$, and leaf carbon isotope composition $\left(\delta^{13} \mathrm{C}\right)$ at $350 \mu \mathrm{mol}$ photons $\mathrm{m}^{-2} \mathrm{~s}^{-1}$ from whole-shoot gas exchange of 18 accessions of Arabidopsis selected from the larger panel of accessions to represent extremes in $\delta^{13} \mathrm{C}$. Open and filled symbols represent spring and winter accession means, respectively. Lines represent linear regression; $r^{2}$ and $P$ values are given

\section{Variation in structure}

In experiment 3, we examined 39 natural accessions of Arabidopsis for variation in $\delta^{13} \mathrm{C}$ and LWC (Table 1). We found a significant negative correlation between $\delta^{13} \mathrm{C}$ and

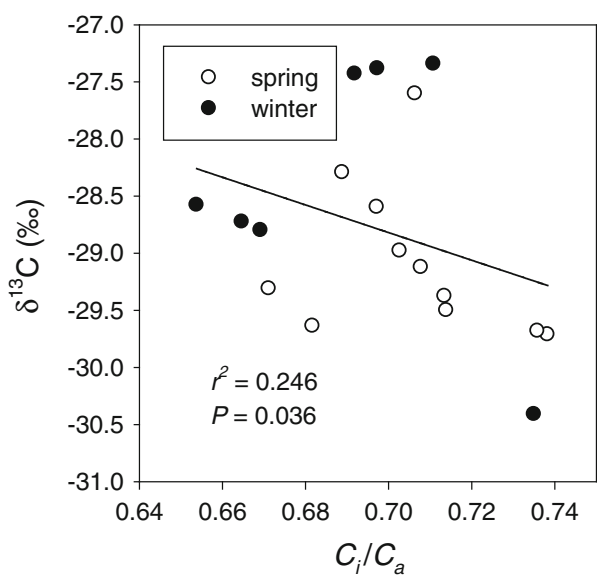

Fig. 4 Relationship between the ratio of intercellular to atmospheric partial pressure $\mathrm{CO}_{2}\left(C_{\mathrm{i}} / C_{\mathrm{a}}\right)$ at $350 \mu \mathrm{mol}$ photons $\mathrm{m}^{-2} \mathrm{~s}^{-1}$ and carbon isotope composition $\left(\delta^{13} \mathrm{C}\right)$. Open and filled symbols represent spring and winter accession means, respectively. Line represents linear regression; $r^{2}$ and $P$ values are given
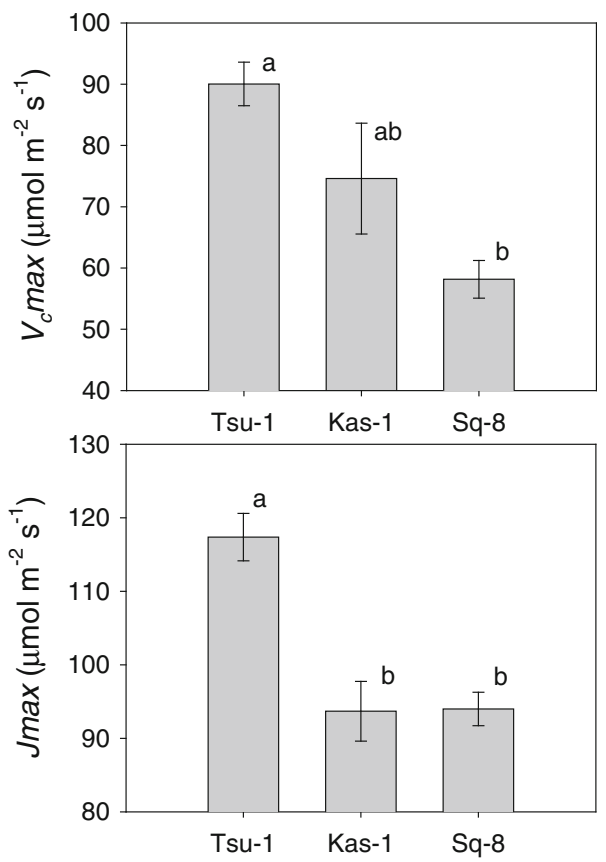

Fig. 5 Maximum carboxylation rate of rubisco $\left(V_{\mathrm{c}} \max \right)$ and maximal photosynthetic electron transport ( Jmax) obtained from photosynthetic carbon dioxide response curves in three accessions (Tsu-1, Sq8, and Kas-1) which differed in $A$. Each bar represents the mean $\pm \mathrm{SE}(n=4)$ for each accession. Letters represent significant differences among accessions. Genotype F-ratio $=12.14$ and $P=0.0078$ for $V_{\mathrm{c}} \max$. Genotype F-ratio $=11.01$ and $P=0.0098$ for $J \max$

LWC among accessions $\left(r^{2}=0.6, P<0.0001\right)$. Spring accessions tended to have higher LWC and lower WUE, as indicated by $\delta^{13} \mathrm{C}$, than winter accessions. Accession differences in LWC most likely result from the effect of mesophyll cell wall thickness on leaf density and not 
differences in water potential as plants in experiment 3 were not water stressed (Garnier and Laurent 1994; Evans et al. 1994). Leaf anatomical traits such as leaf and cell wall thickness, surface area of mesophyll cells exposed to internal air spaces, and the location of chloroplasts within those cells was initially shown to correlate with $g_{\mathrm{m}}$ several decades ago (von Caemmerer and Evans 1991; Evans et al. 1994). In particular, mesophyll cell wall thickness was shown to negatively affect $g_{\mathrm{m}}$. Therefore, high LWC accessions should have thinner mesophyll cell walls resulting in high $g_{\mathrm{m}}$ and more negative $\delta^{13} \mathrm{C}$ (Evans et al. 1994), which is consistent with our data. These ideas have been revisited recently and the importance of the cell wall properties (thickness and water content) and the coverage of air exposed surfaces of mesophyll cells by chloroplasts is receiving more attention (Evans et al. 2009; Tholen and Zhu 2011; Tosens et al. 2012). Direct measurement of leaf thickness and density may explain some of the variation in $g_{\mathrm{m}}$ and $\delta^{13} \mathrm{C}$ among plants with similar LWC values (Fig. 6). Alternatively, variation in COO-porin content or activity could be responsible for the $g_{\mathrm{m}}$ and $\delta^{13} \mathrm{C}$ variation in plants with LWC. Recent studies have found a significant role for chloroplast membrane $\mathrm{CO}_{2}$ transporting aquaporins (COO-porin) has been demonstrated and provides a clearly heritable mechanism for both rapid and sustained adjustment of $g_{\mathrm{m}}$ (Flexas et al. 2006; Uehlein et al. 2008, 2012; Heckwolf et al. 2011). We have found strong correlations between $\mathrm{LWC}, A$, and $g_{\mathrm{s}}$, so focusing on plants with similar LWC should limit the influence of those factors on variation in $\delta^{13} \mathrm{C}$ and increase the relative influence of $g_{\mathrm{m}}$ from cell wall properties or COO-porin content or activity on $\delta^{13} \mathrm{C}$ variation.

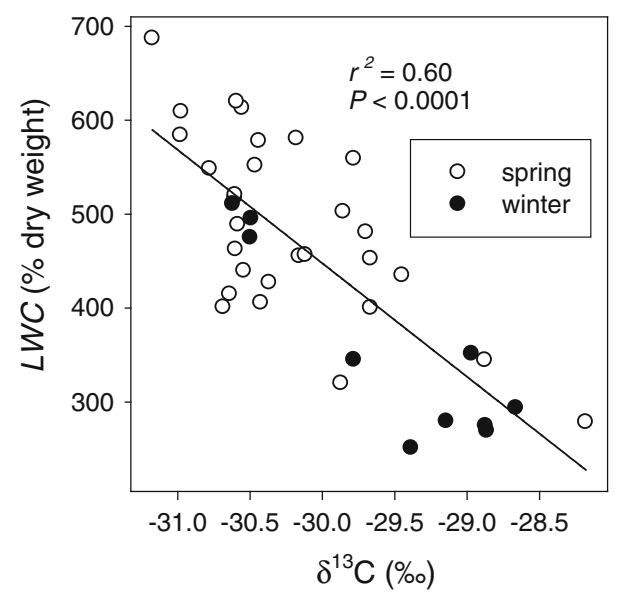

Fig. 6 Relationship between leaf water content (LWC) and leaf carbon isotope composition $\left(\delta^{13} \mathrm{C}\right)$ among 39 accessions of Arabidopsis thaliana. Open and filled symbols represent spring and winter accession means, respectively. Line represents linear regression; $r^{2}$ and $P$ values are given
The ABI4 transcription factor causes changes in leaf anatomy and mesophyll conductance

To further test for a causal effect of leaf anatomy on gas exchange (experiment 4 in Table 1), we used abi4, a mutant of locus AT2G40220, which is an AP2/ERF transcription factor (TF). ABI4 is closely related to the DREB2 TFs and the mutant was initially described as ABA insensitive based on a germination screen (Finkelstein 1994). Subsequent work has shown that the transcript is expressed in seedlings (Soderman et al. 2000) and fully developed rosette leaves (Finkelstein et al. 1998). In addition to its key role in ABA signaling, further characterization of this transcription factor has proposed a large and diverse set of functions including sugar signaling and response (Husijer et al. 2000; Bossi et al. 2009), and root development (Signora et al. 2001; Shkolnik-Inbar and BarZvi 2011). There are hundreds of loci whose expression is altered in the ABI4 mutant (Kerchev et al. 2011). Given that it is a transcription factor, this is not surprising, but does illustrate the challenge of functional annotation of such pleiotropic loci.

abi4 had higher SLA and LWC than wildtype, revealing a novel effect of this TF on leaf anatomy. In addition, abi4 had increased $g_{\mathrm{m}}$ and more negative $\delta^{13} \mathrm{C}$, consistent with the idea that SLA causes variation in $\delta^{13} \mathrm{C}$ via effects on $g_{\mathrm{m}}$ (Fig. 7). The correlation of SLA, $A$, and $g_{\mathrm{s}}$ with LWC helps to explain why LWC is strongly correlated with leaf gas exchange, i.e., LWC appears to be an inverse proxy for cell wall thickness. When taken together, our data show that Arabidopsis leaves trade-off high WUE for low $A$, by trading off leaf anatomy based diffusional $\mathrm{CO}_{2}$ limitation with water loss through stomata. Essentially, plants with the highest $A$ achieve this via the combination of high $g_{\text {s }}$ and thin leaves (high SLA). High $g_{\mathrm{s}}$ keeps $C_{\mathrm{i}}$ high and the thin leaves have cells with thin walls. Thin walls increase $g_{\mathrm{m}}$ and keeps $\mathrm{CO}_{2}$ concentration at the sites of carboxylation $\left(C_{\mathrm{c}}\right)$ high (Evans et al. 1994). Conversely, when photosynthesis is directly limited by the combination of cool winter temperatures and high light through effects on electron transport, then low $g_{\mathrm{s}}$ would be selected for to improve WUE. We hypothesize that thicker leaves would provide more internal shading and more efficient light use, further decreasing $g_{\mathrm{m}}$ and $C_{\mathrm{c}}$ explaining the winter annual phenotype.

Although, a few of the AP2/ERF transcription factors in Arabidopsis have been the subject of detailed study, there are 122 of these loci in Arabidopsis (Nakano et al. 2006) and much remains unknown about their function. Recent studies have revealed increasingly complex roles for members of this transcription factor family. For example, a recent study identified eight AP2/ERFs induced by photorespiration (Foyer et al. 2012). This, combined with the 
Fig. 7 Comparison of specific leaf area (SLA), leaf water content (LWC), mesophyll conductance $\left(g_{\mathrm{m}}\right)$, and leaf carbon isotope composition $\left(\delta^{13} \mathrm{C}\right)$ between abi4-1 and Columbia (Col) wildtype. Each bar represents the mean $\pm \mathrm{SE}$ $(n=7)$ for each genetic line. $P<0.05$ for $g_{\mathrm{m}}$, SLA, LWC, and $\delta^{13} \mathrm{C}$
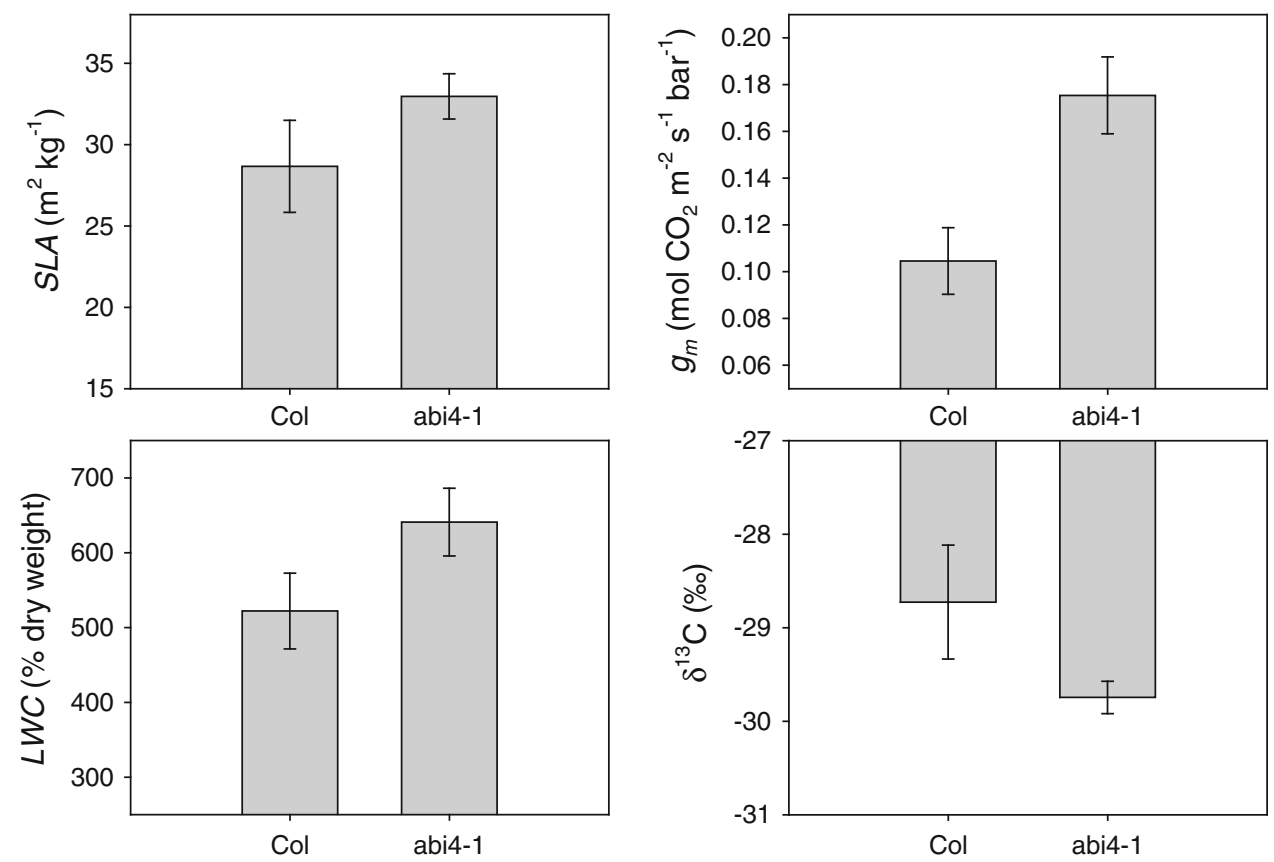

known roles of ABI4 in sugar signaling to photosynthesis including repression of RBCS (Van Oosten et al. 1997; Teng et al. 2008), and our results showing effects on leaf density and $g_{\mathrm{m}}$, are expanding this picture.

\section{Conclusions}

Detailed measurements on a diverse set of accessions detail the traits underlying natural variation in intrinsic WUE and carbon isotope composition. Previous studies have shown that spring accessions have lower intrinsic WUE than accessions with winter life histories. Proportional changes in $A, g_{\mathrm{s}}, V_{\mathrm{c}} \max$, and $J \max$ suggest acclimation of these processes are closely coupled. We also show strong covariation between LWC and $\delta^{13} \mathrm{C}$, where spring annuals tend to have higher LWC and lower intrinsic WUE. We hypothesize that this is due to an effect through $g_{\mathrm{m}}$, and test this hypothesis using the abi4 mutant. The abi4 mutant shows increased SLA and reduced $g_{\mathrm{m}}$ compared to the wildtype, consistent with the pattern of covariance found in the natural accessions.

Previous separate studies in Arabidopsis have addressed variation in $\delta^{13} \mathrm{C}$, plant-water relations, leaf anatomy, and photosynthetic capacity and limitations, including $g_{\mathrm{m}}$. Here, we use a whole canopy approach to examine variation and covariation in all of these components. As predicted by optimality, these traits are not independent, but instead covary as would be expected if selection and photosynthetic acclimation favors states of colimitation. In addition, we show that perturbation of a single transcription factor leads to this trait covariance. This emphasizes the need for whole plant approaches and high dimensional phenotyping to accurately annotate the gene function.

Acknowledgments We thank P Rispin for help in completing the TE experiment. This research is supported by NSF grants DEB-1022196 and DEB-0618302 to JKM, DEB-0618347 to TEJ, IOS-0719118 to DTH, DEB-0618294 to JHR, USDA NIFA 2007-35100-18379 to TEJ, and NIH-NCRR P20RR18754. Support from the California and Colorado Agricultural Experiment Stations is also acknowledged.

Open Access This article is distributed under the terms of the Creative Commons Attribution License which permits any use, distribution, and reproduction in any medium, provided the original author(s) and the source are credited.

\section{References}

Araus JL, Slafer GA, Reynolds MP, Royo C (2002) Plant breeding and drought in $\mathrm{C}_{3}$ cereals: what should we breed for? Ann Bot 89:925-940

Barbour MM, McDowell NG, Tcherkez G, Bickford CP, Hanson DT (2007) A new measurement technique reveals rapid postillumination changes in the carbon isotope composition of leafrespired $\mathrm{CO}_{2}$. Plant Cell Environ 30:469-482

Barbour MM, Warren CR, Farquhar GD, Forrester G, Brown H (2010) Variability in mesophyll conductance between barley genotypes, and effects on transpiration efficiency and carbon isotope discrimination. Plant Cell Environ 33:1176-1185

Bloom AJ, Chapin FS III, Mooney HA (1985) Resource limitation in plants: an economic analogy. Annu Rev Ecol Syst 16:363-392

Bossi F, Cordoba E, Dupre P, Mendoza MS, Roman CS, Leon P (2009) The Arabidopsis ABA-INSENSITIVE (ABI) 4 factor acts as a central transcription activator of the expression of its own 
gene, and for the induction of $A B I 5$ and SBE2.2 genes, during sugar signaling. Plant J 59:359-374

Bouchabke O, Chang F, Simon M, Voisin R, Pelletier G, DurandTardif M (2008) Natural variation in Arabidopsis thaliana as a tool for highlighting differential drought responses. PLoS One 3:e1705

Buckley TN, Mott KA (2002) Dynamics of stomatal water relations during the humidity response: implications of two hypothetical mechanisms. Plant Cell Environ 25:407-419

Caruso CM, Maherali H, Mikulyuk A, Carlson K, Jackson RB (2005) Genetic variance and covariance for physiological traits in Lobelia: are there constraints on adaptive evolution? Evolution 59:826-837

Christman MA, Richards JH, McKay JK, Stahl EA, Juenger TE, Donovan LA (2008) Genetic variation in Arabidopsis thaliana for night-time leaf conductance. Plant Cell Environ 31: $1170-1178$

Comstock JP (2002) Hydraulic and chemical signalling in the control of stomatal conductance and transpiration. $\mathrm{J}$ Exp Bot 53: 195-200

Condon AG, Richards RA, Farquhar GD (1987) Carbon isotope discrimination is positively correlated with grain-yield and drymatter production in field-grown wheat. Crop Sci 27:996-1001

Condon AG, Richards RA, Rebetzke GJ, Farquhar GD (2002) Improving intrinsic water-use efficiency and crop yield. Crop Sci 42:122-131

Cowan IR (1986) Economics of carbon fixation in higher plants. In: Givnish TJ (ed) On the economy of plant form and function. Cambridge U Press, Cambridge, pp 133-170

Dawson TE, Mambelli S, Plamboeck AH, Templer PH, Tu KP (2002) Stable isotopes in plant ecology. Annu Rev Ecol Syst 33: 507-559

Des Marais DL, McKay JK, Richards JH, Sen S, Wayne T, Juenger TE (2012) Physiological genomics of response to soil drying in diverse Arabidopsis accessions. Plant Cell 24:893-914

Donovan LA, Ehleringer JH (1994) Potential for selection on plants for water-use efficiency as estimated by carbon isotope discrimination. Amer J Bot 81:927-935

Donovan LA, Maherali H, Caruso CM, Huber H, de Kroon H (2011) The evolution of the worldwide leaf economics spectrum. Trends Ecol Evo 26:88-95

Evans JR, Sharkey TD, Berry JA, Farquhar GD (1986) Carbon isotope discrimination measured concurrently with gas exchange to investigate $\mathrm{CO}_{2}$ diffusion in leaves of higher plants. Aust $\mathrm{J}$ Plant Physiol 13:281-292

Evans JR, von Caemmerer S, Setchell BA, Hudson GS (1994) The relationship between $\mathrm{CO}_{2}$ transfer conductance and leaf anatomy in transgenic tobacco with a reduced content of rubisco. Aust J Plant Physiol 21:475-495

Evans JR, Kaldenhoff R, Genty B, Terashima I (2009) Resistances along the $\mathrm{CO}_{2}$ diffusion pathway inside leaves. J Exp Bot 60:2235-2248

Farquhar GD, Sharkey TD (1982) Stomatal conductance and photosynthesis. Annu Rev Plant Physiol 33:317-345

Farquhar GD, von Caemmerer S, Berry JA (1980) A biochemical model of photosynthetic $\mathrm{CO}_{2}$ assimilation in leaves of $\mathrm{C}_{3}$ species. Planta 149:78-90

Farquhar GD, O'Leary MH, Berry JA (1982) On the relationship between carbon isotopic discrimination and intercellular carbon dioxide concentration in leaves. Aust J Plant Physiol 9:121-137

Farquhar GD, Ehleringer JR, Hubrick KT (1989) Carbon isotope discrimination and photosynthesis. Annu Rev Plant Physiol 40: 503-537

Finkelstein RR (1994) Mutations at 2 new Arabidopsis ABA response loci are similar to the abi3 mutations. Plant J 5:765-771
Finkelstein RR, Wang ML, Lynch TJ, Rao S, Goodman HM (1998) The Arabidopsis abscisic acid response locus $A B I 4$ encodes an APETALA2 domain protein. Plant Cell 10:1043-1054

Fisher RA, Rees D, Sayre KD, Larque Saavedra A (1998) Wheat yield progress associated with higher stomatal conductance and photosynthetic rate, and cooler canopies. Crop Sci 38:1467-1475

Flexas J, Bota J, Galmes J, Medrano H, Ribas-Carbo M (2006) Keeping a positive carbon balance under adverse conditions: responses of photosynthesis and respiration to water stress. Physiol Plant 127:343-352

Flexas J, Diaz-Espejo A, Galmes J, Kaldenhoff R, Medrano H, RibasCarbo M (2007) Rapid variations of mesophyll conductance in response to changes in $\mathrm{CO}_{2}$ concentration around leaves. Plant Cell Environ 30:1284-1298

Flexas J, Ribas-Carbo M, Diaz-Espejo A, Galmes J, Medrano H (2008) Mesophyll conductance to $\mathrm{CO}_{2}$ : current knowledge and future prospects. Plant Cell Environ 31:602-621

Foyer CH, Neukermans J, Queval G, Noctor G, Harbinson J (2012) Photosynthetic control of electron transport and the regulation of gene expression. J Exp Bot 63:1637-1661

Gallé A, Lautner S, Flexas J, Ribas-Carbo M, Hanson D, Roesgen J, Fromm J (2012) Photosynthetic responses of soybean (Glycine $\max \mathrm{L}$.) to heat-induced electrical signaling are predominantly governed by modifications of mesophyll conductance for $\mathrm{CO}_{2}$. Plant Cell Environ 36:542-552

Garnier E, Laurent G (1994) Leaf anatomy, specific mass and watercontent in congeneric annual and perennial grass species. New Phytol 128:725-736

Geber MA, Dawson TE (1997) Genetic variation in stomatal and biochemical limitations to photosynthesis in the annual plant, Polygonum arenastrum. Oecologia 109:535-546

Geber MA, Griffin LR (2003) Inheritance and natural selection on functional traits. Int J Plant Sci 164:S21-S42

Hall NM, Griffiths H, Corlett JA, Jones HG, Lynn J, King GJ (2005) Relationships between water-use traits and photosynthesis in Brassica oleracea resolved by quantitative genetic analysis. Plant Breeding 124:557-564

Heckwolf M, Pater D, Hanson DT, Kaldenhoff R (2011) The Arabidopsis thaliana aquaporin AtPIP1; 2 is a physiologically relevant $\mathrm{CO}_{2}$ transport facilitator. Plant J 67:795-804

Heschel MS, Donohue K, Hausmann NJ, Schmitt J (2002) Population differentiation and natural selection for water-use efficiency in Impatiens capensis (Balsaminaceae). Int J Plant Sci 163:907-912

Husijer C, Kortsee A, Pego J, Weisbeek P, Wisman E, Smeekens S (2000) The Arabidopsis SUCROSE UNCOUPLED-6 gene is identical to ABSCISIC ACID INSENSITIVE-4: involvement of abscisic acid in sugar responses. Plant J 23:577-585

Juenger TE, McKay JK, Hausmann N, Keurentjes JJB, Sen S, Stowe KA, Dawson TE, Simms EL, Richards JH (2005) Identification and characterization of QTL underlying whole-plant physiology in Arabidopsis thaliana: $\delta^{13} \mathrm{C}$, stomatal conductance and transpiration efficiency. Plant Cell Environ 28:697-708

Juenger TE, Sen S, Bray E, Stahl E, Wayne T, McKay J, Richards JH (2010) Exploring genetic and expression differences between physiologically extreme ecotypes: comparative genomic hybridization and gene expression studies of Kas-1 and Tsu-1 accessions of Arabidopsis thaliana. Plant Cell Environ 33: $1268-1284$

Katul G, Manzoni S, Palmroth S, Oren R (2010) A stomatal optimization theory to describe the effects of atmospheric $\mathrm{CO}_{2}$ on leaf photosynthesis and transpiration. Ann Bot 105:431-442

Kerchev PI, Pellny TK, Vivancos PD, Kiddle G, Hedden P, Driscoll S, Vanacker H, Verrier P, Hancock RD, Foyer CH (2011) The transcription factor $\mathrm{ABI} 4$ is required for the ascorbic acid-dependent regulation of growth and regulation of jasmonate-dependent 
defense signalling pathways in Arabidopsis. Plant Cell 23: 3319-3334

Kogami H, Hanba YT, Kibe T, Terashima I, Masuzawa T (2001) $\mathrm{CO}_{2}$ transfer conductance, leaf structure and carbon isotope composition of Polygonum cuspidatum leaves from low and high altitudes. Plant, Cell Environ 24:529-538

Lasky JR, Des Marais DL, McKay JK, Richards JH, Juenger TE, Keitt TH (2012) The role of geography, climate and phenology in explaining characterizing genomic variation of Arabidopsis thaliana: the roles of geography and climate. Mol Ecol 12: $5512-5529$

Littell RC, Milliken GA, Stroup WW, Wolfinger RD (1996) SAS system for mixed models. SAS Institute Inc, Cary, p 633

Masle J, Gilmore SR, Farquhar GD (2005) The ERECTA gene regulates plant transpiration efficiency in Arabidopsis. Nature 436:866-870

McKay JK, Richards JH, Mitchell-Olds T (2003) Genetics of drought adaptation in Arabidopsis thaliana: I. Pleiotropy contributes to genetic correlations among ecological traits. Mol Ecol 12: $1137-1151$

McKay JK, Richards JH, Nemali KS, Sen S, Mitchell-Olds T, Boles S, Stahl EA, Wayne T, Juenger TE (2008) Genetics of drought adaptation in Arabidopsis thaliana II. QTL analysis of a new mapping population, Kas-1 $\times$ Tsu-1. Evolution 62:3014-3026

Monda K, Negi J, Iio A, Kusumi K, Kojima M, Hashimoto M, Sakakibara H, Iba K (2011) Environmental regulation of stomatal response in the Arabidopsis Cvi-0 ecotype. Planta 234:555-563

Nakano T, Suzuki K, Fujimura T, Shinshi H (2006) Genome-wide analysis of the ERF gene family in Arabidopsis and rice. Plant Physiol 140:411-432

Nordborg M, Hu TT, Ishino Y, Jhaveri J, Toomajian C, Zheng H, Bakker E, Calabrese P, Gladstone J, Goyal R, Jakobsson M, Kim S, Morozov Y, Padhukasahasram B, Plagnol V, Rosenberg NA, Shah C, Wall JD, Wang J, Zhao K, Kalbfleisch T, Schulz V, Kreitman M, Bergelson J (2005) The pattern of polymorphism in Arabidopsis thaliana. PLoS Biol 3:e196

Parkhurst DF, Mott KA (1990) Intercellular diffusion limits to $\mathrm{CO}_{2}$ uptake in leaves. Plant Physiol 94:1024-1032

Passioura JB (1977) Grain yield, harvest index, and water use of wheat. J Aust I Agr Sci 43:117-120

Pons TL (2012) Interaction of temperature and irradiance effects on photosynthetic acclimation in two accessions of Arabidopsis thaliana. Photosynth Res 113:207-219

Rebetzke GJ, Condon AG, Richards RA, Farquhar GD (2002) Selection for reduced carbon isotope discrimination increases aerial biomass and grain yield of rainfed bread wheat. Crop Sci 42:739-745

Reich PB, Walters MB, Ellsworth DS (1997) From tropics to tundra: global convergence in plant functioning. Proc Natl Acad Sci USA 94:13730-13734

SAS Institute (1999) SAS/STAT user's guide. SAS Institute Inc., Cary

Schulze E-D (1986) Carbon dioxide and water exchange in response to drought in the atmosphere and in the soil. Annu Rev Plant Physiol 37:247-274

Seibt U, Rajabi A, Griffiths H, Berry JA (2008) Carbon isotopes and water use efficiency: sense and sensitivity. Oecologia 155: $441-454$
Sharkey TD, Bernacchi CJ, Farquhar GD, Singsaas EL (2007) Fitting photosynthetic carbon dioxide response curves for $\mathrm{C}_{3}$ leaves. Plant Cell Environ 30:1035-1040

Shkolnik-Inbar D, Bar-Zvi D (2011) Expression of ABSCISIC ACID INSENSITIVE 4 (ABI4) in developing Arabidopsis seedlings. Plant Signal Behav 6:694-696

Signora L, De Smet I, Foyer CH, Zhang H (2001) ABA plays a central role in mediating the regulatory effects of nitrate on root branching in Arabidopsis. Plant J 28:655-662

Söderman EM, Brocard IM, Lynch TJ, Finkelstein RR (2000) Regulation and function of the Arabidopsis ABA-insensitive4 gene in seed and abscisic acid response signaling networks. Plant Physiol 124:1752-1765

Syvertsen JP, Lloyd J, Mcconchie C, Kriedemann PE, Farquhar GD (1995) On the relationship between leaf anatomy and $\mathrm{CO}_{2}$ diffusion through the mesophyll of hypostomatous leaves. Plant, Cell Environ 18:149-157

Teng S, Rognoni S, Bentsink L, Smeekens S (2008) The Arabidopsis GSQ5/DOG1 Cvi allele is induced by the ABA-mediated sugar signalling pathway, and enhances sugar sensitivity by stimulating ABI4 expression. Plant J 55:372-381

Terashima I, Hanba YT, Tholen D, Niinemets U (2011) Leaf functional anatomy in relation to photosynthesis. Plant Physiol 155:108-116

Tholen D, Zhu XG (2011) The mechanistic basis of internal conductance: a theoretical analysis of mesophyll cell photosynthesis and $\mathrm{CO}_{2}$ diffusion. Plant Physiol 156:90-105

Tosens T, Niinemets U, Vislap V, Eichelmann H, Diez PC (2012) Developmental changes in mesophyll diffusion conductance and photosynthetic capacity under different light and water availabilities in Populus tremula: how structure constrains function. Plant Cell Environ 35:839-856

Uehlein N, Otto B, Hanson DT, Fischer M, McDowell N, Kaldenhoff R (2008) Function of Nicotiana tabacum aquaporins as chloroplast gas pores challenges the concept of membrane $\mathrm{CO}_{2}$ permeability. Plant Cell 20:648-657

Uehlein N, Otto B, Eilingsfeld A, Itel F, Meier W, Kaldenhoff R (2012) Gas-tight triblock-copolymer membranes are converted to $\mathrm{CO}_{2}$ permeable by insertion of plant aquaporins. Sci Rep 2:538

Van Oosten JJM, Gerbaud A, Huijser C, Dijkwel PP, Chua NH, Smeekens SCM (1997) An Arabidopsis mutant showing reduced feedback inhibition of photosynthesis. Plant J 12:1011-1020

Von Caemmerer S, Evans JR (1991) Determination of the average partial-pressure of $\mathrm{CO}_{2}$ in chloroplasts from leaves of several $\mathrm{C}_{3}$ plants. Aust J Plant Physiol 18:287-305

Warren CR (2008) Does growth temperature affect the temperature responses of photosynthesis and internal conductance to $\mathrm{CO}_{2}$ ? A test with Eucalyptus regnans. Tree Physiol 28:11-19

Warren CR, Adams MA (2006) Internal conductance does not scale with photosynthetic capacity: implications for carbon isotope discrimination and the economics of water and nitrogen use in photosynthesis. Plant Cell Environ 29:192-201

Warren CR, Dreyer E, Adams MA (2003) Photosynthesis-Rubisco relationships in foliage of Pinus sylvestris in response to nitrogen supply and the proposed role of Rubisco and amino acids as nitrogen stores. Trees 17:359-366

Yamori W, Noguchi K, Terashima I (2006) Mechanisms of temperature acclimation of photosynthesis. Plant Cell Physiol 47:S4 